\title{
錫/錫の固相接合界面の酸化皮膜に対する 酢酸による改質効果
}

\author{
小山真司 大屋一生*
}

群馬大学大学院工学研究科

J. Japan Inst. Metals, Vol. 74, No. 11 (2010), pp. 733-739

(C) 2010 The Japan Institute of Metals

\section{Effect of Surface Modification by Acetic Acid on Superficial Oxide Film of the Solid-State Bonded Joint of Tin}

\author{
Shinji Koyama and Issei Oya* \\ Graduate School of Engineering, Gunma University, Kiryu 376-8515
}

The effect of acetic acid surface modification on the superficial oxide film that covers the solid-state bonded joint of tin has been investigated by conducting SEM and TEM observations of the interfacial microstructures and fractured surfaces. Acetic acid surface modification was carried out by boiling a tin surface in acetic acid for $900 \mathrm{~s}$. Solid-state bonding was carried out in a vacuum chamber at a bonding temperature $T$ of $403-483 \mathrm{~K}$ and a bonding pressure $P$ of $7 \mathrm{MPa}$ (bonding time $=1800 \mathrm{~s}$ ). It was observed that the bond strength increased with the bonding temperature, regardless of the acetic acid surface modification. Because of surface modification, bonded joints were obtained at a bonding temperature that was $40 \mathrm{~K}$ lesser than the typical temperature required, and the bond strength was comparable to that of the base metal. When the joint strength was much lower than the base metal strength, belt-like inclusions were found to be distributed in the interfacial region. As the joint strength increased with bonding temperature, these inclusions were coarsened, and their distribution density decreased. The increase in bond strength with bonding temperature corresponded well with the observed change in the size and density of the inclusions. This tendency was observed at a bonding temperature that was $40 \mathrm{~K}$ lesser than that of the joint that did not undergo surface modification. Therefore, it is believed that the joint that underwent surface modification possessed a high tensile strength despite having a low bonding temperature; this is because tin (II) acetate coheres at a temperature lower than required for the coherence of an oxide film, and the area of the metal-to-metal contact increased at a low temperature.

(Received April 21, 2010; Accepted July 8, 2010)

Keywords: tin, solid-state bonding, microstructure, bond strength, surface modification, acetic acid

\section{1. 緒言}

近年の電子機器の軽薄短小化に伴い, 電子部品の高密度実 装の要求が高まっており, 半導体チップなどの電子部品をべ アチップの状態でダイレクトに基板に搭載するフリップチッ プ実装が用いられてきた1-3). 従来のフリップチップ実装 は, はんだバンプをチップの実装面拉よ゙基板に形成し, 溶 融させて接合していたが，この手法では，はんだを溶融させ るため, さらなる高密度実装に伴う多ピン化, 狭ピッチ化に 対して限界が指摘され, はんだを溶融させない手法として, 固相接合を利用した実装法が利用され始めている。例えば， 超音波を用いて接合面の污染層を破壊・除去後に接合する方 法 ${ }^{4-8)}$, あるいは半導体チップのバンプ表面および基板のパ ッド表面にプラズマを照射して接合面の污染層を除去後に接 合する方法9-12)などが挙げられる.このように, 実際の接合 面には酸化皮膜が存在するため, 固相接合による接合面どう しの金属接合を達成するためには，污染層の除去が必須のプ
ロセスとなる．特にウェハレベルパッケージングなどの多点 一括接合では, 接合信頼性向上のために接合時に高温に加熱 しなければならず，大きな熱的ダメージが与えられ，基板の 反りや熱膨張差による残留応力は大きな課題となってい る13-15). また，接合時に必要な荷重は一括して接合される バンプの数に比例し, ウェハどうしの接合を想定した場合に 与えられる荷重は, 非常に大きなものとなることが容易に推 測される.

本研究では, フリップ実装におけるバンプと基板の電極端 子間の接続などの, 低温・低荷重で接合を必要とする箇所へ の固相接合の適用を検討するため, はんだの主要元素である 錫を研究対象として，その表面を酢酸中で煮沸することによ り接合表面の改質を行い，その継手性能を評価することで， 接合表面酸化皮膜に対する改質効果を明らかにしようとし た.このため, 処理表面同士をつき合わせて固相接合し, 得 られた継手の接合界面組織や固相接合強さに対してどのよう な影響を及ぼすかを調べ, 引張試験後の破面の観察結果も併 せて検討を加えた。

* 群馬大学大学院生 (Graduate Student, Gunma University) 


\section{2. 実 験 方 法}

実験に用いた接合用試験片は，錫ブロック $(5 \times 15 \times 15$ $\mathrm{mm}^{3}$ )に引張試験機への取り付け用として, 直方体の銅ブロ ック $\left(10 \times 15 \times 15 \mathrm{~mm}^{3}\right)$ を接合し，Fig. 1 に示す形状に成型 した後，接合面となる一対の錫表面を，加工層の除去および 平滑化を目的とした電解研磨により仕上げた。電解液には, $5 \mathrm{vol} \%$ 過塩素酸 $+10 \mathrm{vol} \%$ ブトキシエタノール $+85 \mathrm{vol} \%$ エ チルアルコール溶液を用い, 電解液中で温度 $273 \mathrm{~K}$, 電圧 $14 \mathrm{~V}$ の条件で $120 \mathrm{~s}$ ，電解研磨を行った．酢酸による表面改 質処理は，錫表面を煮沸した酢酸 $(99 \%)$ 中 (約 $391 \mathrm{~K})$ で, 0.6〜 $1.2 \mathrm{ks}$ 煮沸することにより行った。 また表面改質処理 により接合表面に形成された生成物の同定には, $\mathrm{X}$ 線回折 装置 (理学電機製，RINT2100V/PC，Cu K $\alpha ， 32 \mathrm{kV} ， 20$ $\mathrm{mA}$ )を用いた.

以上により作製した接合用試験片の錫表面同士をつき合わ せて，真空炉中で接合時間を $1.8 \mathrm{ks}$ ，接合圧力を $7 \mathrm{MPa}$ に 設定して，接合温度を $403 \sim 483 \mathrm{~K}$ の間で変化させて接合し た。なお，酢酸により改質処理した表面の酸化あるいは吸湿 による変化をできるだけ抑えるため，処理後 $180 \mathrm{~s}$ 以内に接 合用試験片を真空炉中に設置するようにした.

得られた継手の界面強度は，引張試験によって評価した。 引張試験片の形状は，長さ，幅および厚さがそれぞれ約 25 $\mathrm{mm}, 12 \mathrm{~mm}$ 抢よび $3.5 \mathrm{~mm}$ で，接合面に垂直方向を長手方 向とし, この方向に引張試験した. 引張試験にはインストロ ン型試験機 (INSTRON 製，5567) を用い，变位速度 0.017 $\mathrm{mm} / \mathrm{s}$ とした。組織観察は，接合界面に垂直方向の断面を走 査電子顕微鏡 (SEM: Scanning Electron Microscope, JEOL 製，JSM-5310）を用いて，加速電圧 $15 \mathrm{kV}$ で行った。観察 面は，エメリー紙を用いて 2000 番まで研磨した後，既述の 電解液を用いて電解研磨し，さらに $2 \mathrm{vol} \%$ 塩酸 +エチルア ルコール溶液で腐食して組織を現出させた．透過電子顕微鏡 (TEM: Transmission Electron Microscope)による観察用試 験片は，収束イオンビーム加工装置 (FIB： Focused Ion Beam，日立ハイテクノロジーズ製，FB-2000S)により作製 した。TEM 観察は JEOL 製, JEM2010 (加速電圧 $200 \mathrm{kV}$ )

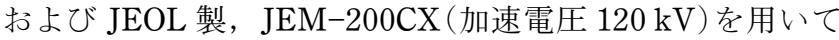
行った.

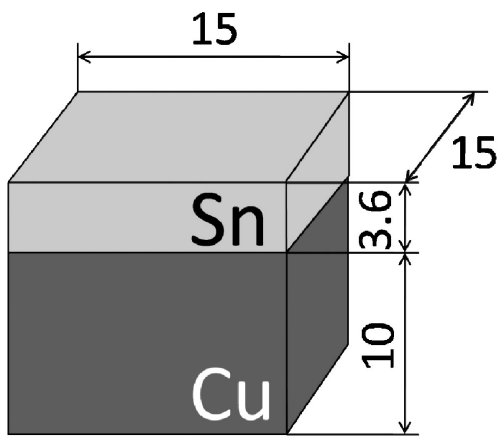

Fig. 1 Schematic illustration of specimen to be bonded (in $\mathrm{mm})$.

\section{3. 実 験 結 果}

\section{1 界面強度に対する酢酸の表面改質効果}

酢酸の接合界面強度に及ぼす表面改質処理時間の影響を調 べるため，接合温度および接合時間をそれぞれ $453 \mathrm{~K}$ およ び $1.8 \mathrm{ks}$ で一定とし，処理時間を $0.6 \sim 1.2 \mathrm{ks}$ に変化させて 接合し，得られた継手の接合界面特性を比較することにより 処理時間の最適化を行った．処理時間と継手の引張強さの関 係を Fig. 2 に示し，引張試験後の破面の外観写真を Fig. 3 に示す．処理時間と継手の引張強さの関係から (Fig. 2)，処 理時間を $0.9 \mathrm{ks}$ とした場合に最も高い引張強さを有する継 手が得られることが分かった。 また, 破断部の外観観察の結 果 (Fig. 3)，処理時間が $0.9 \mathrm{ks}$ の場合のみ断面収縮を示した 後に破断していた。したがって，処理時間が $0.6 \mathrm{ks}$ および $1.2 \mathrm{ks}$ の場合は，界面強度の低い領域があるために引張強さ が低下したものと考えられる。処理時間 $0.6 \mathrm{ks}$ 抢よび 1.2 ks の場合に抢いて界面破断した要因を調べるため，界面破 断部をSEM により観察した。その結果，処理時間が $0.6 \mathrm{ks}$ の場合は, Fig. 4(a)に示すように，延性的な破断形態は認 められず脆性的な破断形態を示していた。脆性的に破断した のは，処理時間が短いため，後述する錫の酸化皮膜の酢酸錫 （II）への置換が不十分となり，錫の酸化皮膜中で破断したた めであると考えられる。また処理時間が $1.2 \mathrm{ks}$ の場合は, Fig. 4 (c)に示すように，ティアリッジが認められるもの の, 直径 $1 \mu \mathrm{m}$ 程度の微細な粒子で破面全面が覆われてい た.この微細な粒子は, 後述するように, 表面改質処理によ り酸化皮膜を含む錫の母相が酢酸錫 $($ II $)$ に置換され，引き続 いて接合中の加熱により分解生成した酸化第二錫であると考 えられる。これらの酸化第二錫と考えられる粒子の分布密度 は，処理時間が $0.9 \mathrm{ks}$ の場合に比べ $1.2 \mathrm{ks}$ の方がはるかに 高く, また一方で分布密度の増加に伴い継手の引張強さが減 少傾向を示すことから，表面改質層すなわち酢酸錫（II）の過 唾形成により接合中に多量の酸化第二錫を生成し，酸化物中 あるいは酸化物と錫母相間で脆性的に破断した結果，接合界 面強度が低下したものと考えられる。一方，処理時間が 0.9 $\mathrm{ks}$ の場合は, Fig. 4(b)に示すように, 直径 $1 \mu \mathrm{m}$ 程度の微 細なディンプルが認められ，破面の全面で延性的な破断形態 を示していた。これらの結果から，最適な処理時間は $0.9 \mathrm{ks}$

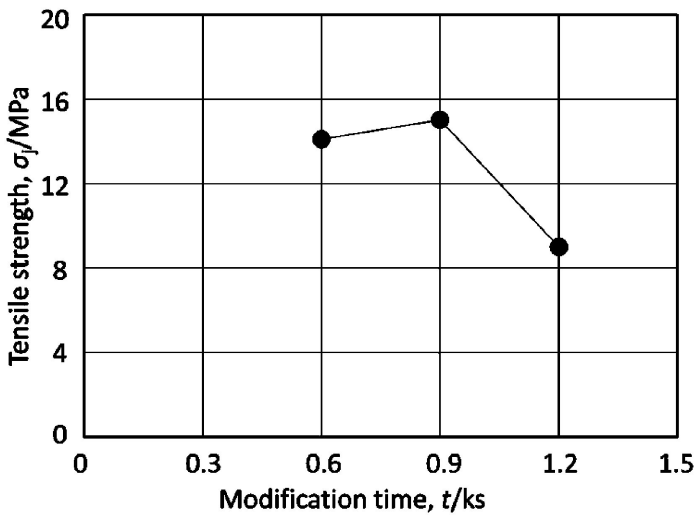

Fig. 2 Relation between tensile strength and modification time. 

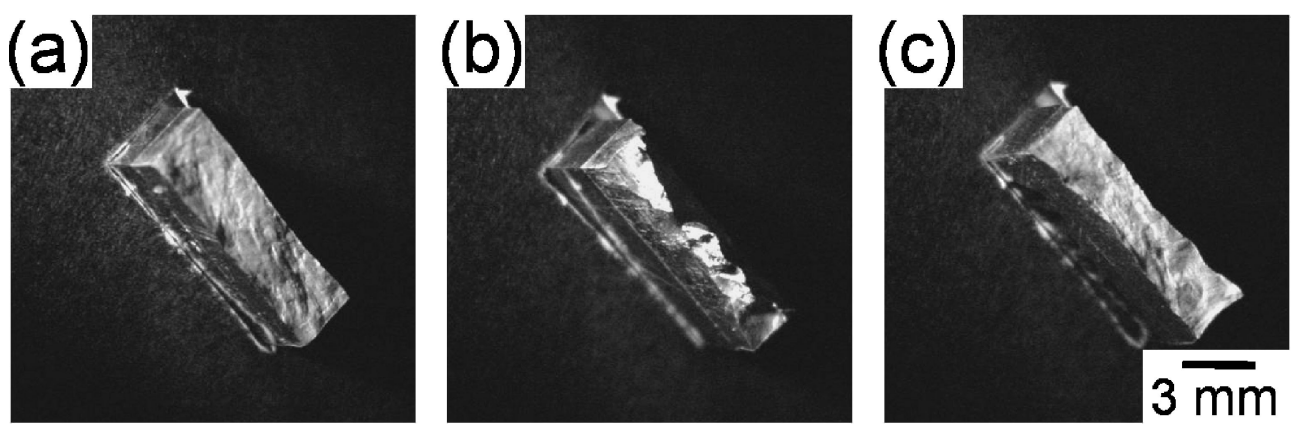

Fig. 3 Optical macroscopic images of fractured surfaces of joints after tensile test: (a) $t=0.6 \mathrm{ks}$, (b) $t=0.9 \mathrm{ks}$ and (c) $t=1.2 \mathrm{ks}$.
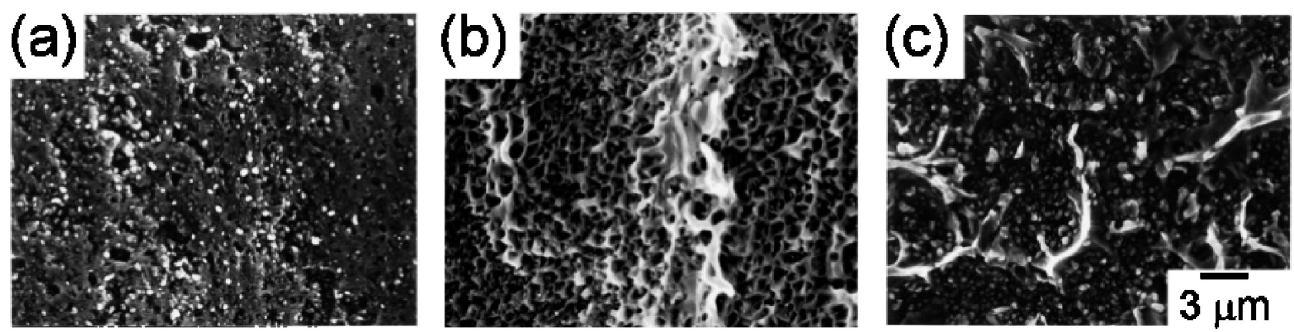

Fig. 4 SEM micrographs of fractured surfaces of joints after tensile test: (a) $t=0.6 \mathrm{ks}$, (b) $t=0.9 \mathrm{ks}$ and (c) $t=1.2 \mathrm{ks}$.

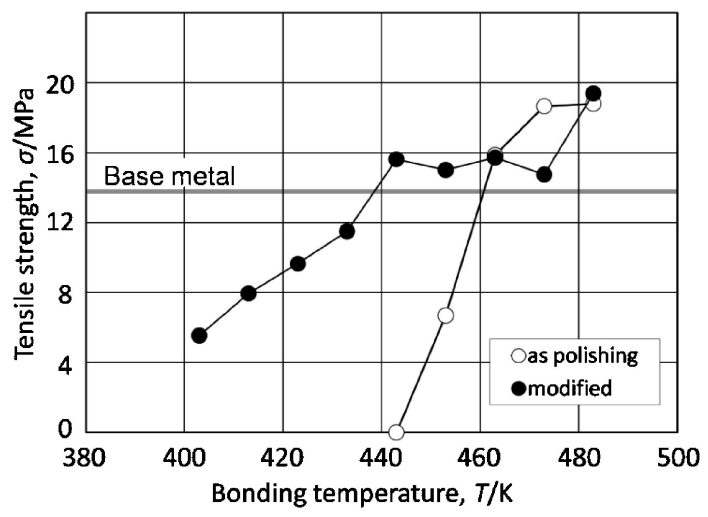

Fig. 5 Effect of the surface modification on the relation between joint efficiency of joint and bonding temperature. The bonding pressure and time for all joints were $7 \mathrm{MPa}$ and $1.8 \mathrm{ks}$ respectively.

であると判断した。この最適処理時間を用いて，酢酸により 錫の接合面を改質処理した場合，継手の引張強さが接合温度 とともにどのように変化するかを Fig. 5 に示す。図中には 比較のため, 酢酸による表面改質処理を施さず, 電解研磨仕 上げしたままの接合表面を用いた場合の測定結果も示した。 Fig. 5 に示されるように，表面改質処理の有無に関わらず， 継手の引張強さは接合温度の上昇とともに増加する傾向を示 したが，改質処理を施さなかった場合は 453〜 463 K の接合 温度範囲で大きな引張強さの上昇がみられるのに対して, 酢 酸により改質処理を施すことで，403〜 443 K の範囲で緩や かな引張強さの上昇がみられた. したがって酢酸により改質 処理を施すと, 約 $50 \mathrm{~K}$ 低い接合温度から継手の引張強さが 増加し始めることが分かった。 また破面に掞いて，界面破断 した領域が全く認められず，断面収縮を示した後に錫中で母 材破断する継手の得られる接合温度は, 改質処理の有無に関 わらず $483 \mathrm{~K}$ 以上であった。 なお，それ以下の接合温度範 (a)
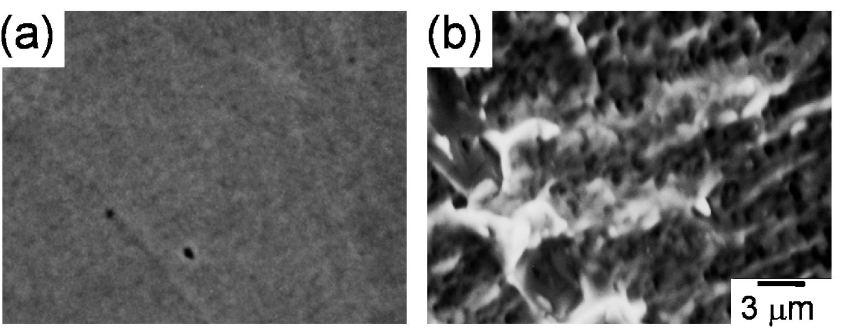

Fig. 6 SEM micrographs of fractured surfaces of joints after tensile test: (a) $T=443 \mathrm{~K}$ and (b) $T=463 \mathrm{~K}$.
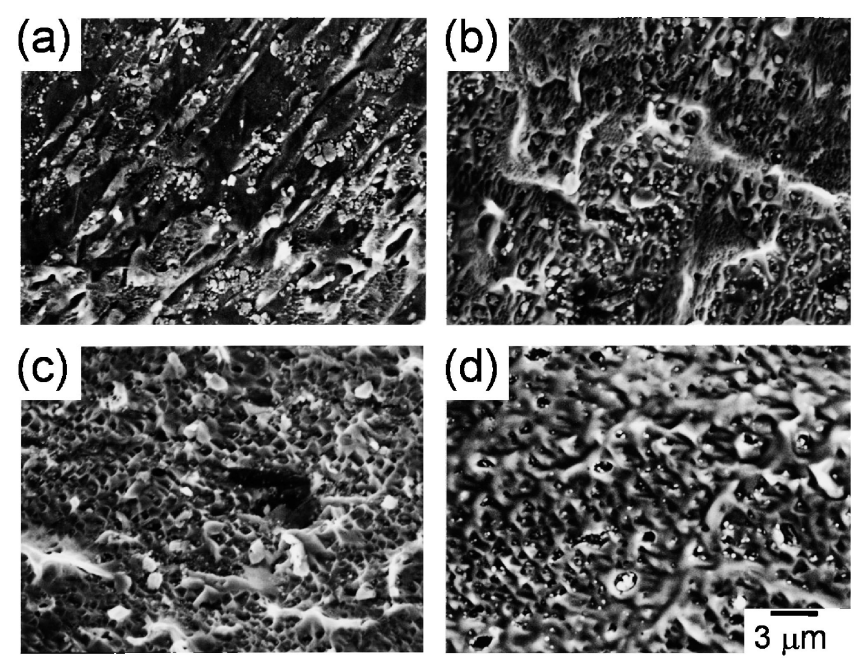

Fig. 7 SEM micrographs of fractured surfaces of joints after tensile test: (a) $T=403 \mathrm{~K}$, (b) $T=423 \mathrm{~K}$, (c) $T=443 \mathrm{~K}$ and (d) $T=463 \mathrm{~K}$.

囲ではいずれの場合も界面破断部が認められた.

界面破断した要因を調べるため，界面破断部を SEM によ り観察した．観察結果を Fig. 6 および Fig. 7 に示す.

酢酸による表面改質処理を施さなかった場合, 接合温度が 
453 K 以下では，Fig. 6 (a)に示すように，破断面は滑らか で脆性的な破断形態を示した。接合温度を $463 \mathrm{~K}$ に上昇さ せると, Fig. 6(b)に示すように, 微細なディンプル状の延 性的な破断形態を示すようになり, ディンプルの底には直径 $1 \mu \mathrm{m}$ 以下の微細な粒子が認められた. この変化の生じる接 合温度域は継手の引張強さが増加した温度域とほぼ一致して おり, またディンプル状の延性的な破断形態が認められた接 合温度 $463 \mathrm{~K}$ は錫の母材並みの引張強さを有する継手が得 られた接合温度と一致していた(Fig. 5 参照).

一方, 酢酸により表面改質処理を施した場合, 接合温度が $403 \mathrm{~K}$ では, Fig. 7 (a)に示すように，滑らかな破断領域と 直径 $1 \mu \mathrm{m}$ 以下の白色を呈した粒子が複数個集まって分布し ている様子が認められた。接合温度を $423 \mathrm{~K}$ に上昇させる と，滑らかな破断形態は認められなくなり，ティアリッジあ るいはディンプル状の延性的な破断形態が一部で認められる ようになった (Fig. 7(b)). また接合温度 $403 \mathrm{~K}$ で認められ た直径 $1 \mu \mathrm{m}$ 以下の白色を呈した粒子が分散して分布してい る様子が認められた。 さらに接合温度を $443 \mathrm{~K}$ に上昇させ ると, Fig. 7(c)に示すように, 破面の全面でティアリッジ あるいはディンプル状の延性的な破断形態に変化した．また 破面上には, 直径 $1 \sim 2 \mu \mathrm{m}$ 程度に粗大化した白色を呈した
粒子が多数認められた。しかしながら接合温度を $463 \mathrm{~K} に$ 上昇させても, Fig. 7 (d) に示すように, 微細な白色を呈し た粒子は粗大化することなく破面上に残存し, 引張試験後の 破断形態も錫中での母材破断には至らず，界面破断部が残存 した. 以上の観察結果から, 接合温度を $423 \mathrm{~K}$ 以上に上昇 させると, 破面上の脆性的な破断形態は認められなくなり, 破面全面でディンプルやティアリッジからなる延性的な破断 形態に変化し, この接合温度域は高い引張強さを有する継手 の得られる接合温度域と一致することが分かった (Fig. 5 参 照). したがって, 接合温度の上昇とともに接合界面の介在 物が凝集することにより脆性的な破断形態から延性的な破断 形態に変化した結果, 継手の引張強さが上昇したものと考え られる. なた, 酢酸により表面改質を施すと, 改質処理を施 さなかった場合に比べ，延性的な破断形態を示す接合温度が 約 $40 \mathrm{~K}$ 低下することが分かった.

\section{2 酢酸により表面改質処理した場合の接合界面組織}

接合界面近傍の組織に及ぼす酢酸による表面改質効果につ いて検討するため, 接合界面近傍の組織を SEM により観察 した. 観察結果を Fig. 8 抢よび Fig. 9 に示す.なお接合界 面は, 図中の黒矢印で示す領域である.

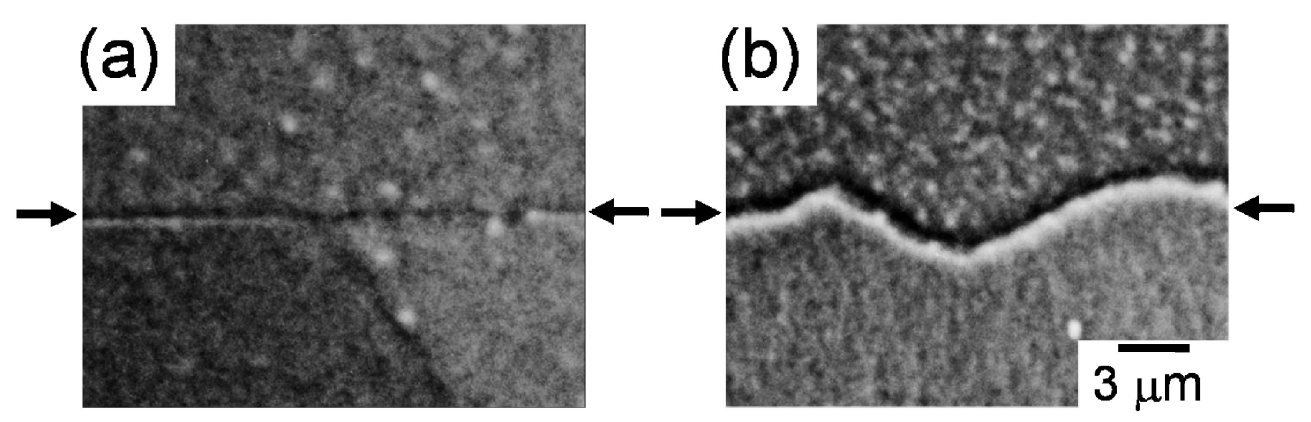

Fig. 8 SEM micrographs of bond interface: (a) $T=443 \mathrm{~K}$ and (b) $T=463 \mathrm{~K}$.
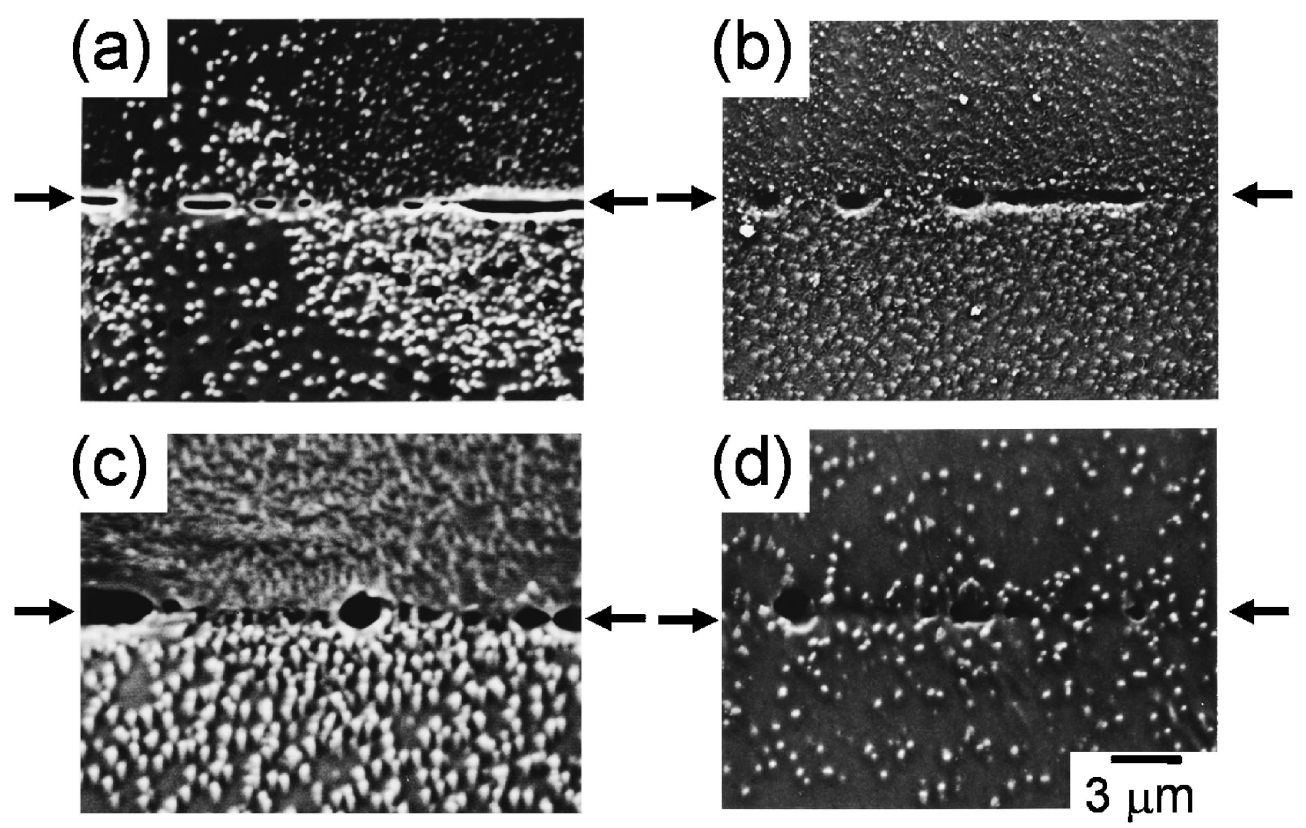

Fig. 9 SEM micrographs of bond interface: (a) $T=403 \mathrm{~K}$, (b) $T=423 \mathrm{~K}$, (c) $T=443 \mathrm{~K}$ and (d) $T=463 \mathrm{~K}$. 


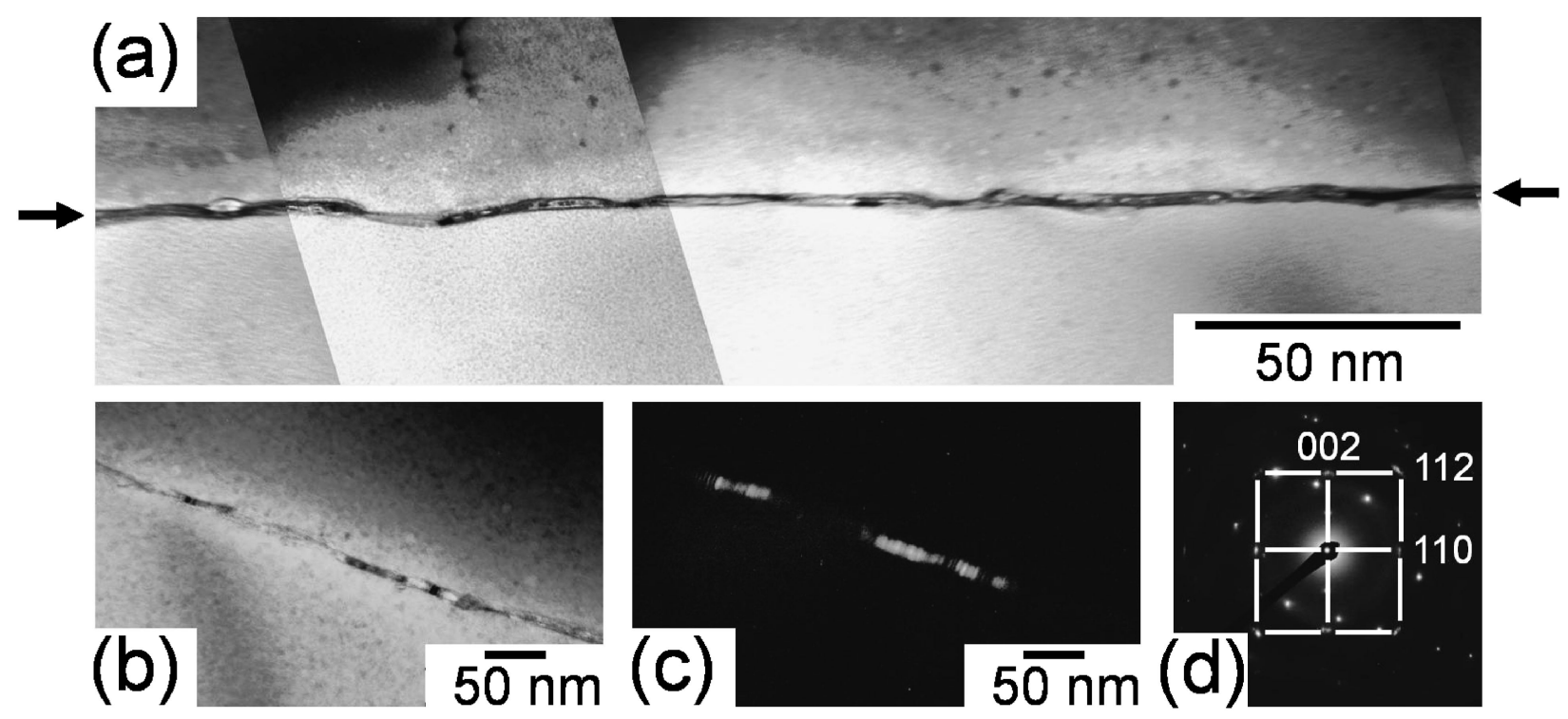

Fig. 10 TEM micrographs of oxide film of $\mathrm{SnO}$ at a joint interface $(T=443 \mathrm{~K})$ : (a) bright field image, (b) bright field image in (a), (c) dark field image and (d) SAD pattern.
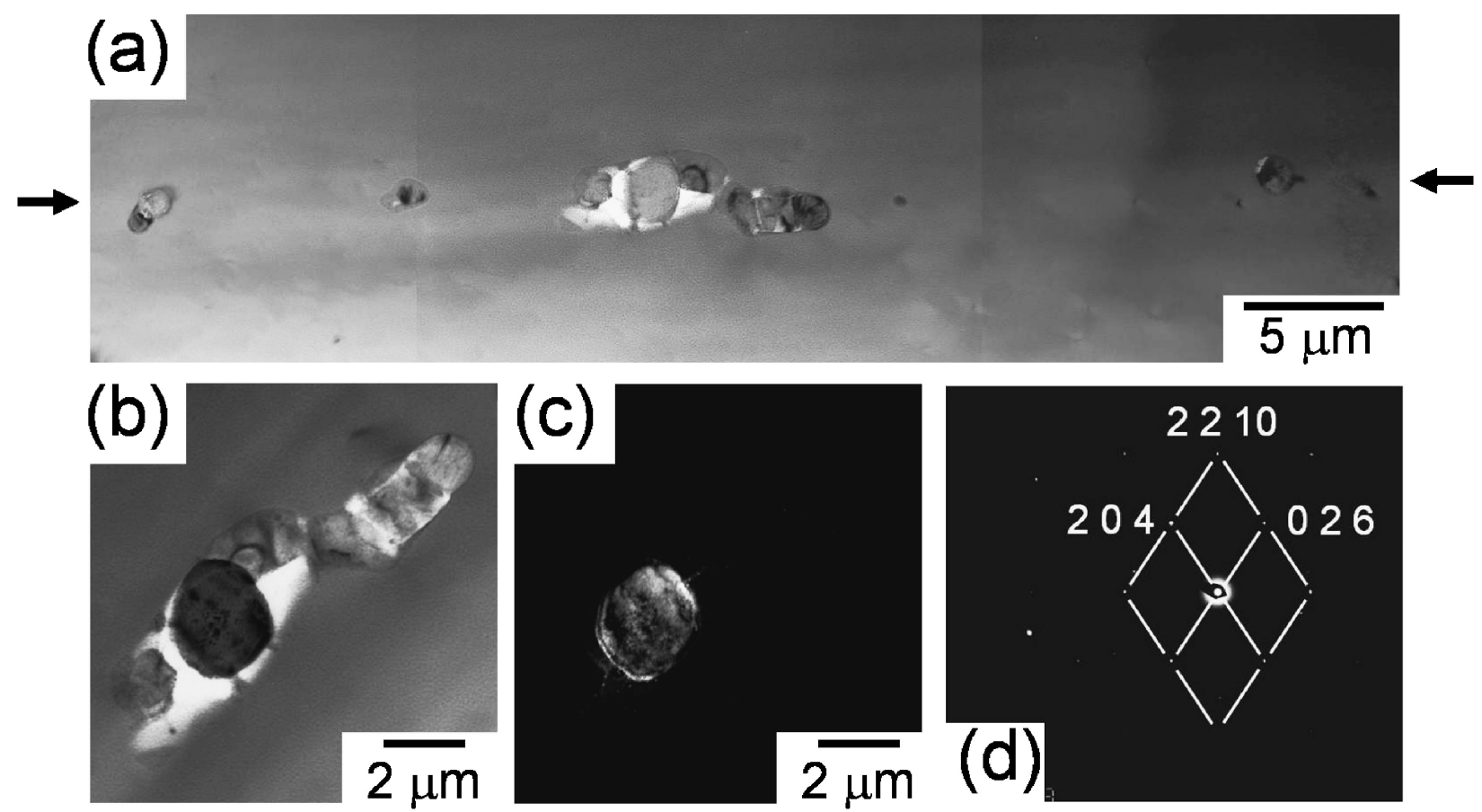

Fig. 11 TEM micrographs of oxide in particle of $\mathrm{SnO}_{2}$ at a joint interface $(T=443 \mathrm{~K})$ : (a) bright field image, (b) bright field image in (a), (c) dark field image and (d) SAD pattern.

酢酸による表面改質処理を施さなかった場合，接合温度が $453 \mathrm{~K}$ 以下では, Fig. 8(a)に示すように, 直線状の接合線 が明瞭に認められた。接合温度を $463 \mathrm{~K}$ に上昇させると接 合線は明瞭に認められるが，接合界面の結晶粒界が接合線か ら最大で $2 \mu \mathrm{m}$ 程度移動している領域が一部に認められるよ うになった (Fig. 8(b))。これは前報で述べたように, 錫の 自己拡散によるものであると考えられる16).

一方, 酢酸により表面改質処理を施した場合, 接合温度が 403 K では, Fig. 9(a)に示すように，接合界面には厚さが 1 $\mu \mathrm{m}$ 以下で幅が数 $\mu \mathrm{m}$ の帯状の介在物あるいはボイドが認め られた. 後述するように, 接合界面近傍には少なくとも接合
前には酢酸錫 (II) が形成されており, 組織観察のための電解 研磨中や組織現出のための腐食中に溶媒中へ溶出しやすいと 考えられるため, このボイドのように見える孔は, 組織観察 用試験片の作製時に電解液中へ介在物が溶解あるいは脱落し た痕跡と考えられる.これらの介在物は分布密度から判断し て, 破面上に認められた微細粒子が複数個集まった領域に相 当すると考えられる. したがって, 接合界面に高密度の介在 物が分布している場合は, 高い引張強さを示さず, 介在物内 部あるいは錫母相と介在物間で脆性的に破断することが分か った．接合温度を $423 \mathrm{~K}$ 以上に上昇させると，Fig. 9(b)〜 (d)に示すように, 帯状の介在物は認められなくなり, 塊状 
化した介在物が増加するとともに分布密度が減少する傾向を 示した.これらの観察結果から, 接合温度の上昇とともに接 合界面近傍の介在物が凝集 · 粗大化し, 錫母相同土の金属的 接触をした領域が増加することにより継手の引張強さが上昇 することが分かった。

次に接合界面近傍を TEM により観察した結果を Fig. 10 および Fig. 11 に示す。なお接合界面は, 図中の黒矢印で示 す領域である。

酢酸により表面改質を施さなかった場合，接合温度 $443 \mathrm{~K}$ では，Fig. 10（a）に矢印間に示すように，接合界面近傍には 厚さ $10 \mathrm{~nm}$ 程度の帯状の介在物が認められた. この帯状介 在物は, Fig. 10 (b) に示す帯状介在物を含む領域の SAD パ ターンから, 斜方晶の酸化第一錫と指数付けされた(Fig. $10(\mathrm{~d})$ ). 酸化第一錫の 112 反射の回折線を用いて撮影した 暗視野像を Fig. 10 (c)に示す。したがって接合温度 $443 \mathrm{~K}$ で接合した継手は，連続的な酸化皮膜が接合界面に存在する ために脆性的な破断形態を示し, その結果, 引張強さが低か ったものと推察される.

一方, 酢酸により表面改質を施すと, 接合温度 $443 \mathrm{~K}$ で は, Fig. 11(a)の黒矢印間に示すように, 直径数 $\mu \mathrm{m}$ 程度の 塊状の介在物が接合界面に分散して分布している様子が認め られた。この塊状の介在物は, 大きさ抢よび分布密度から判 断して, 引張試験後の破面のディンプルの底に認められた白 色を呈した粒子の断面組織と考えられる. この塊状の介在物 は, Fig. 11(b)に示す塊状の介在物を含む領域の SAD パ ターンから, 斜方晶の酸化第二錫と指数付けされた (Fig. $11(\mathrm{~d}))$. 酸化第二錫の 204 反射の回折線を用いて撮影した 暗視野像を Fig. 11(c)に示す.酢酸錫 (II)は, 式 (1)に示す 反応過程を経ることで熱により分解し, 針状, 三角形あるい は四角形等の変化に富んだ形状の酸化第二錫結晶を生成する ことが知られている17).

$$
2 \mathrm{Sn}\left(\mathrm{CH}_{3} \mathrm{COO}\right)_{2}+9 \mathrm{O}_{2} \longrightarrow 2 \mathrm{SnO}_{2}+8 \mathrm{CO}_{2} \uparrow+6 \mathrm{H}_{2} \mathrm{O} \uparrow
$$

したがってこの塊状の酸化第二錫は，接合中に酢酸錫（II）が 分解生成, あるいは接合前に形成された自然酸化皮膜が凝集 して生成したのではないかと考えられる．これらのことか ら, 接合温度 $443 \mathrm{~K}$ で接合した継手は, 接合界面の介在物 の分布密度が低いためにディンプル状の延性的な破断形態を 示し, その結果, 錫の母材強度に匹敵する継手が得られたも のと推察される.なお, TEMの観察領域内には, ボイドな どの孔が認められなかったことから, SEM による観察結果 で認められた孔はボイドではなく, 組織現出時の介在物の脱 落あるいは溶解によるものであることが示唆された (Fig. 9 参照).

\section{4. 考 察}

表面改質処理を施さず，電解研磨仕上げした錫どうしを固 相接合した場合，接合界面には酸化第一錫からなる厚さ 10 $\mathrm{nm}$ 程度の帯状に分布した酸化物が認められた (Fig. 10 参 照).これらの酸化皮膜および錫母相は, 酢酸と長時間煮沸 することにより酢酸錫 (II) を生成すると言われている18).
これらの生成反応式を式 $(2) \sim(4)$ に示す.

$$
\begin{aligned}
& \mathrm{Sn}+2 \mathrm{CH}_{3} \mathrm{COOH} \longrightarrow \mathrm{Sn}\left(\mathrm{CH}_{3} \mathrm{COO}\right)_{2}+\mathrm{H}_{2} \uparrow \\
& \mathrm{SnO}+2 \mathrm{CH}_{3} \mathrm{COOH} \longrightarrow \mathrm{Sn}\left(\mathrm{CH}_{3} \mathrm{COO}\right)_{2}+\mathrm{H}_{2} \mathrm{O} \\
& \mathrm{SnO}_{2}+2 \mathrm{CH}_{3} \mathrm{COOH} \longrightarrow \mathrm{Sn}\left(\mathrm{CH}_{3} \mathrm{COO}\right)_{2}+\mathrm{H}_{2}+\mathrm{O}_{2}
\end{aligned}
$$

すなわち, 酢酸による改質操作により, 少なくとも接合表面 近傍には $\mathrm{Sn}\left(\mathrm{CH}_{3} \mathrm{COO}\right)_{2}$ からなる酢酸錫（II）が生成してい るものと考えられる. そこで本研究で用いた改質処理時間 $(0.9 \mathrm{ks})$ を用いて酢酸中で煮沸した錫表面を XRD により解 析した. その結果 Fig. 12 に示すように, 錫母相や酸化第二 錫の回折ピークも認められるものの, 酢酸錫 (II)の回折ピー クが認められ, 酢酸で煮沸することにより酢酸錫 (II) が生成 することが裏付けられた.

表面酸化皮膜を含む錫の酢酸による改質作用を調べるた め, 厚さ $7 \mu \mathrm{m}$ の錫䈃 (約 $12.4 \mathrm{mg}$ ) を酢酸中で $0.9 \mathrm{ks}$ 煮沸 し, 直ちに示差走査熱量計 (DSC: Differential Scanning Calorimeter, SII 製, DSC6200)を用いてDSC 測定を行っ た. 測定結果を Fig. 13 に示す. 測定結果から, 本研究で用 いた接合温度範囲近傍には，415～478 K に発熱ピークが認 められ，415〜 $442 \mathrm{~K}$ の間に大きな発熱反応 (1) を生じた 後, 小さな発熱反応 (2) が $478 \mathrm{~K}$ まで続く傾向を示した. なお, 測定温度範囲内において, 純錫であれば融点以外に吸 熱あるいは発熱ピークは認められない。したがって本測定で 認められた発熱ピークは, 改質処理により得られたものであ

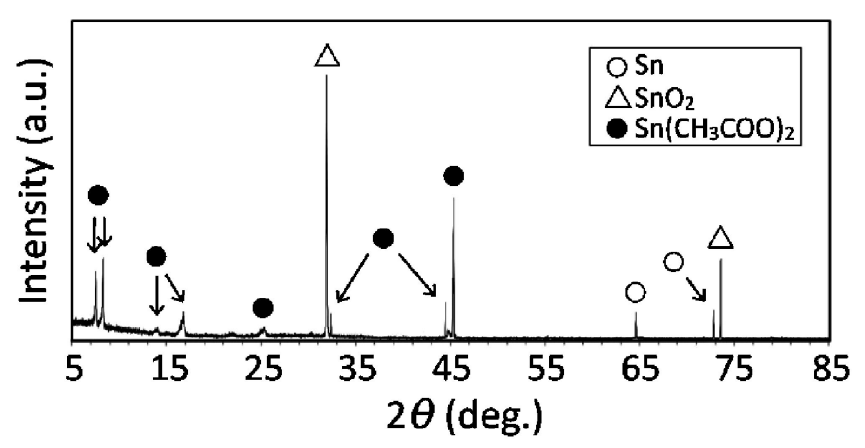

Fig. $12 \mathrm{X}$-ray diffraction patterns of the surface modificated by acetic acid for $0.9 \mathrm{ks}$.

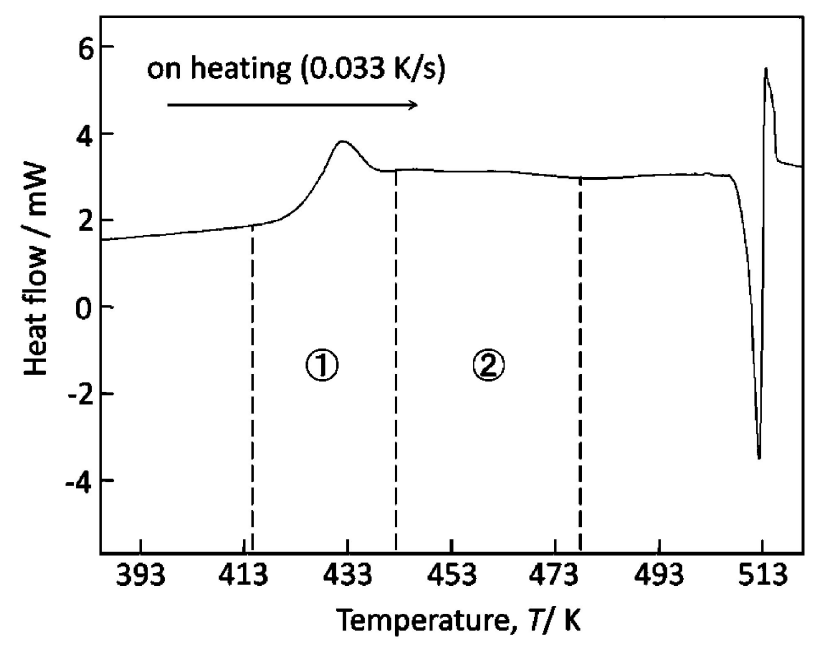

Fig. 13 DSC curves of modified tin by acetic acid. The modifying time was $0.9 \mathrm{ks}$. 
る。また，測定温度 $505 \mathrm{~K}$ 近傍の吸熱ピークは，錫母材の 溶融によるものである。ここで, 接合温度 403〜 433 K は, 大きな発熱ピークを有する温度域(1) に相当し，この温度域 では, 引張試験後の破面観察の結果, 脆性的な破断形態から 延性的な破断形態へと変化していた。 一方，接合温度 $443 \mathrm{~K}$ 以上は, 小さな発熱ピークを有する温度域(2) に相当し, こ の温度域では, 継手の引張強さが高い值のまま推移していた.

以上のことから, 接合温度 $423 \mathrm{~K}$ 以上から延性的な破断 形態に変化し, 継手の引張強さが向上したのは, 酢酸による 改質操作により接合表面に酢酸錫 (II) が生成し, この生成物 が $415 \mathrm{~K}$ から反応を開始した結果, 錫の酸化物に比べて, より低い接合温度で凝集 · 粗大化し, 分布密度が減少して, 錫母相どうしの真実接触面積が増加したためであると推察さ れる.

\section{5. 結言}

本研究では, 錫の固相接合において, 接合界面の酸化皮膜 に対する酢酸による改質効果について調べ検討を加えた，得 られた結果は以下のように要約される.

（1） XRDによる解析の結果, 酸化皮膜を含む錫の表面 は, 酷酸により改質処理を施すことで少なくとも最表面は酢 酸錫 (II)を生成することが分かった。

（2）DSCによる熱分析の結果, 酢酸錫 (II) は $415 \mathrm{~K}$ 近傍 から発熱反応を生じ, 反応の開始前後の温度域では, 引張試 験後の破断形態が脆性的な形態から延性的な形態へと変化し た.

(3) 接合温度 $443 \mathrm{~K}$ で作製した継手の接合界面近傍を TEM により観察した結果, 改質処理なしの場合は膜状の酸 化物が連続的に分布していたが，改質処理を施すことで塊状 の酸化物が分散分布している様子に変化した。したがって改 質処理を施すことで，より低い接合温度で錫母相ざうしの金 属的接触をした領域が拡大した結果, 低い接合温度で高い引
張強さを有する継手が得られたものと考えられる.

なお, 本研究の一部は財団法人天田金属加工機械技術振興 財団研究助成を受けて遂行した.ここに感謝の意を表す。ま た, TEM 観察にご協力頂いた群馬大学 松村雅夫技術系職 員に謝意を表す。

文献

1) M. Klein, H. Oppermann, R. Kalicki, R. Axchenbrenner and H. Reichl: Microelect. Reliab. 39(1999) 1389-1397.

2) M. J. Wolf, G. Engelmann, L. Dietrich and H. Reichl: Nucl. Instrum. Method. and Phy. Res. A 565 (2006) 290-295.

3) J. Helneder, C. Hoyler, M. Schneegans and H. Torwesten: Microelectronic Eng. 82(2005) 581-586.

4) M. Hizukuri, N. Watanabe and T. Asano: IEEE Trans. Comp. Packag. Manuf. Technol. A 19(2001) 34-40.

5) N. Watanabe and T. Asano: Jpn. J. Appl. Phys. 42 (2003) 21932197.

6) K. Tanida, M. Umemoto, Y. Tomita, M. Tago, R. Kajiwara, Y. Akiyama and K. Takahashi: Jpn. J. Appl. Phys. 42 (2003) 21982203.

7) J. Lee, H. Kim and C. D. Yoo: J. Electron. Mater. 34(2005) 96102.

8) L. Junhui, W. Ruishan, H. Hu, W. Fuliang, H. Lei and Z. Jue: Microelectronic Eng. 86 (2009) 2063-2066.

9) T. Imamura, E. Higurashi, T. Suga and R. Sawada: IEEJ Trans. Sensors and Micromachines 128(2008) 266-270.

10) E. Higurashi, T. Imamura, T. Suga and R. Sawada: IEEE Photon. Tech. Lett. 19(2007) 1994-1996.

11) A. Shigetou, T. Itoh and T. Suga: J. Mater. Sci. 40 (2005) 31493154.

12) Q. Wang, N. Hosoda, T. Itoh and T. Suga: Microelect. Reliab. 43(2003) 751-756.

13) X. J. Fan, B. Varia and Q. Han: Microelect. Reliab. 50(2010) $536-546$.

14) T. Iida, T. Itoh, Y. Takano, A. Sandhu and K. Shikama: SolidState Electron. 43(1999) 1117-1120.

15) J. Ahang, M. O. Bloomfield, J. Q. Lu, R. J. Gutmann and T. S. Cale: Microelectronic Eng. 82(2005) 534-547.

16) S. Koyama and I. Oya: J. Japan Inst. Metals 73(2009) 809-815.

17) E. Kawamata, S. Kamabe and K. Ohshima: Oyo Buturi 46 (1977) 490-499.

18) Y. Shibata and K. Kimura: Muki Kagaku Zensyo VI-1-1 Suzu, (Maruzen 1963) p. 360. 